\title{
Filmless Festivals and Dragon Seals: Independent Cinema in China
}

\section{Markus Nornes}

"Like any new wave or cohesive movement in the history of film, the wave will break. The movement will sputter. This is the only rule of cinema that cannot be broken.”

Those were my words, published in this journal some ten years ago. ${ }^{I}$ In retrospect, I realize those years marked the peak of the independent cinema in China. Returning a decade later, I hereby offer an update from the ruins-to use a metaphor borrowed from Beijing Film Academy professor Zhang Xianmin. Many of the institutional structures are left from before, he suggests, but they are largely empty or half standing. Although China is poised to overtake Hollywood as the largest movie industry in the world, it is entering what some have called a "post-independent cinema" era. To summarize: ten years ago marked the beginning of the end, and today marks the beginning of another beginning.

\section{Amid the Ruins}

The hot spots of 2009 are gone. The financier who had bankrolled the archive and screenings at the Iberia gallery in Beijing's 798 Art District decided it did matter that he couldn't capitalize on documentary and video art, and sloughed off those activities. His collection, the China Independent Film Archive, went into exile-first in Hong Kong, and finally in Brussels, where it became one of the standing ruins. After many troubled years, the anthropological institute in Kunming that hosted Yunfest (the Yunnan Multi Culture Visual Festival) pulled its support; the festival's programmers retreated to ethnographic work on music and other spheres of cultural production. May Fest was the modest event run by $\mathrm{Wu}$ Wenguang, who essentially inaugurated the independent cinema movement in China in the early I99os. He discontinued his festival in 2014 when his CCD Workstation collective was forced to abandon its beautiful building in Beijing's Caochangdi Art District and move to a village far outside of Beijing's city limits. The reasons

Film Quarterly, Vol. 72, Number 3, pp. 78-86, ISSN 0015-1386, electronic ISSN 1533-8630. (c) 2019 by The Regents of the University of California. All rights reserved. Please direct all requests for permission to photocopy or reproduce article content through the University of California Press's Reprints and Permissions web page, http://www ucpress.edu/journals.php?p=reprints. DOI: https://doi.org/10.1525/FQ.2019.72.2.78.

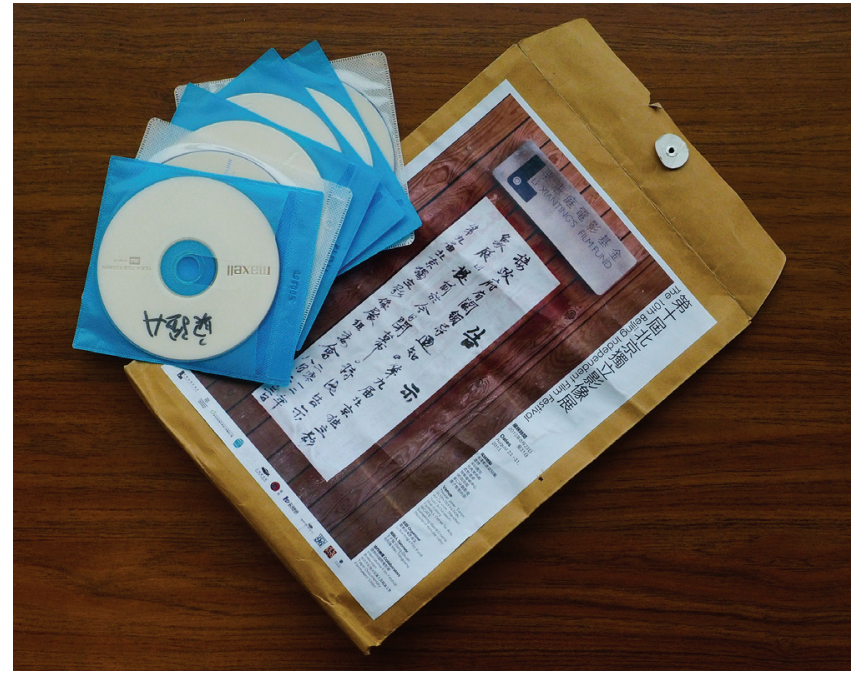

A festival in an envelope: the 2013 Beijing Independent Film Festival.

were economic, not political. His lease was up and the rent became outrageously unaffordable; none other than $\mathrm{Ai}$ Weiwei took it over. (This building escaped the fate of demolition in summer 20I8, when the government tore down Ai's older studio space).

The biggest ruin still standing is in the artist village of Songzhuang. There, the Li Xianting Film Fund combined its fiction and documentary events into the Beijing Independent Film Festival (BIFF) in 20Io. It became by far the most important festival for independent film, and this is probably why it had the most trouble.

In 20I2, the opening screening of Huang Ji's Jidan he shitou (Egg and Stone, 2012) was interrupted by a power failure-one that struck only the neighborhood of the theater. Screenings continued in private venues, and the actions of local authorities were roundly mocked on social media. Jia Zhangke wrote, "Rumor has it the Film Bureau and Power Supply Bureau have merged. Perhaps I should take up the art of shadow puppetry." $^{2}$

The following year, festival preparations included the purchase of electric generators. On one of the first days of the 2013 festival, though, it was ordered to close. This crisis was met with "talk sessions," and, in what must be a first in 


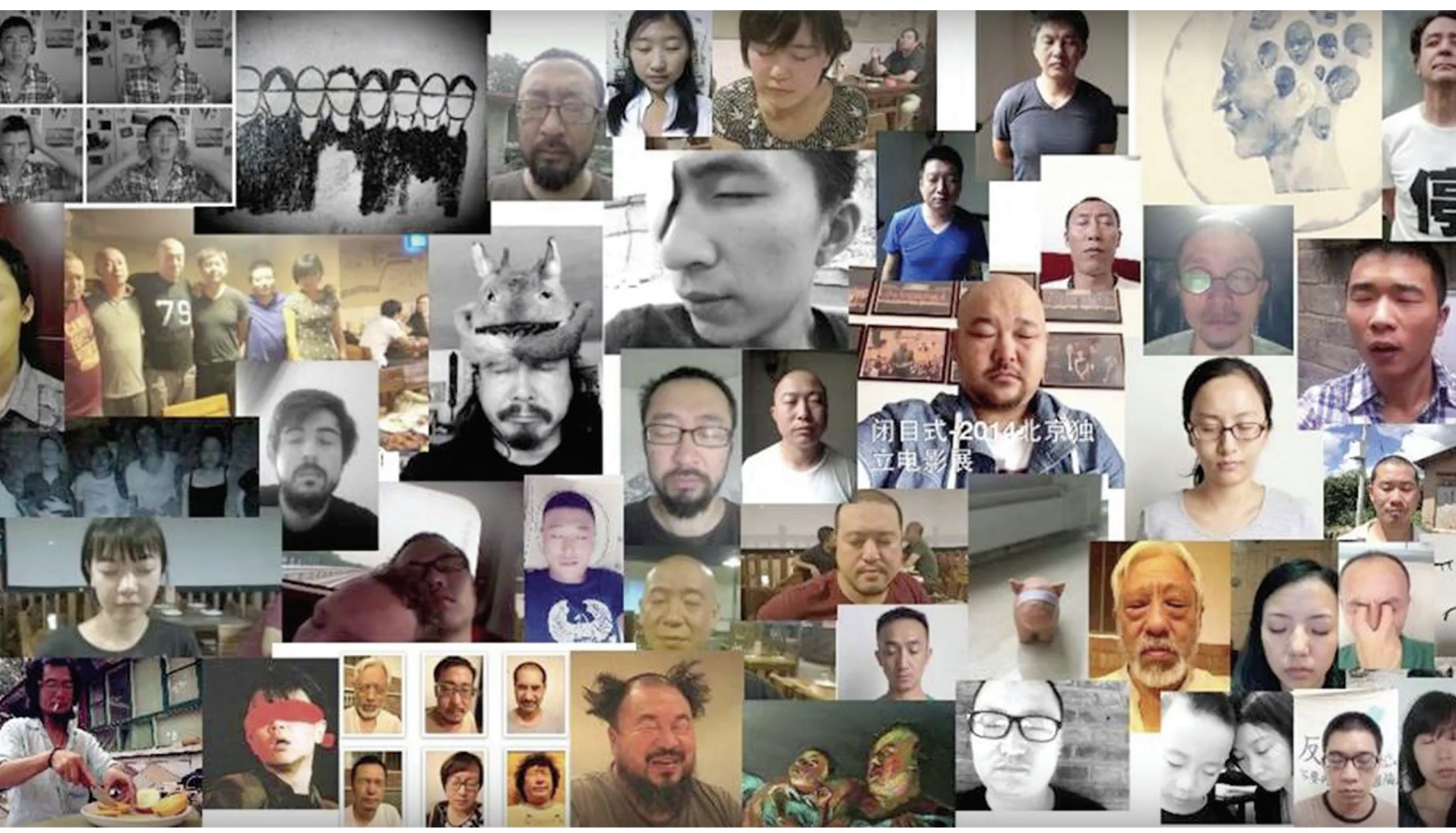

A Filmless Festival: Eyes Closing Ceremony, a social media protest from the 2014 Beijing Independent Film Festival. Courtesy of Wang Wo

film history, organizers rushed to get permissions from directors to distribute a stack of over sixty festival films on DVDs to colleagues and programmers—a festival in a bag. Audiences hung out in the Li Xianting Film Fund courtyard, so the networking and communal side of the festival continued unabated. Then a film was discreetly shown. Nothing happened. And then the festival returned to its schedule for the rest of the week.

The 2014 BIFF, however, was a watershed. Festivalgoers were greeted by goons, there was violence, organizers $\mathrm{Li}$ Xianting and Wang Hongwei were detained briefly, and festival offices were raided. Police actually used ladders to scale the walls of the film fund's compound. Most painfully, the archive of 1,552 titles that the fund had built over the course of a decade was confiscated and has yet to be returned. An experimental documentary by Wang Wo (who also designs BIFF's posters) captured the events through found footage shot by festival visitors. Its title unwittingly captured the festival's future: Meiyou dianying de dianying jie (A Filmless Festival, 2015). ${ }^{3}$

Indeed, during 2015-17, BIFF achieved another first in film history: it literally became a filmless festival. It issued calls for submissions, selected slates of films, published catalogs, constructed juries, and conferred awards. However, it did not show films. Thus did China lose its most important gathering point for independent filmmakers. Since 2016, BIFF has shown a selection of the festival films on weekends throughout the year; however, in 2018 it elected to discontinue all screening activities for the time being. According to actor and festival director Wang Hongwei, "External pressure on our fund is too great and we don't want to make unnecessary sacrifices." 4 The fund does, however, continue activities such as teaching workshops.

The only major indie festival to continue to the present day is the China Independent Film Festival, cofounded by Zhang Xianmin in Nanking. After Zhang left the organization, it moved to Beijing and began to run irregularly and unpredictably. Recent editions have followed the BIFF model, becoming another filmless festival.

\section{Time Out}

Before turning to the present, I want to highlight a serious issue raised by Tang Xiaobing and Akiyama Tamako, who 
have convincingly critiqued the dubious premise underlying the celebrations of the independent Chinese film scene by foreign scholars, critics, and programmers. ${ }^{5}$ Tang has termed it a "dissidence hypothesis" and points to my own early essay as a prototypical example. Akiyama suggests a more useful term: the "discourse of resistance" (teiko no gensetsu). Both argue that these indies have been viewed through a simple binary, pitting a noisy antiauthoritarian documentary against government functionaries of various stripes. This binarism naturally paints a stark division between nonofficial and official, between heroic rebels and oppressive authorities. Censorship becomes the defining feature of independence, an equivalence that, they argue, blinds outsiders to the real complexity of creative practice and exhibition in China-a critique that I find compelling and seek to address here.

In her own writing about the documentary scene in China, Akiyama in particular offers a provocative way out of the discourse of resistance through a metaphor of "cultural asylum." Festivals are posited as refuges or free zones relatively independent from secular rules and regulations through temporary and sometimes tacit, sometimes explicit, approval from the ruling classes. In the I9gos and into the 200os, she argues, the independent film scene was one of many asylums in China-an unofficial, noncommercial field that achieved a measure of autonomy from regulation (especially censorship). Artistic experimentation flourished, and many people were attracted to step inside. Akiyama writes:

In actuality, society is never divided cleanly into the dominant and the dominated. At first glance, even in contemporary Chinese society one can see the control of power in every nook and cranny. But if you push through to the interior it becomes ever so complex. Relationships turn inside out, and spaces protected with some measure of independence and autonomy are interspersed here and there.... The people bearing responsibility for the asylum hold an exceedingly complex symbiosis with the dominant class that allowed their existence. ... [T] he asylum necessarily traverses any number of temporary, provisional relationships, ensuring the continuation of its life by moving from one safe space to the next. ${ }^{6}$

She argues that asylums in illiberal places like contemporary China are not physical spaces, but domains or fields where creativity flourishes, relatively free from top-down regulation. In fact, this sense of openness and safety is created, Akiyama writes, through negotiation, collaboration, and the tacit acknowledgment of authority. It is like an "invisible fortress" with ill-defined borders, although when it takes an institutional form an "edge" appears. (A border can become quite material, too, as in the wall that police scale in A Filmless Festival.)
Put simply, viewed from within the resistance discourse, the Chinese festival scene looks like a simple matter of suppression and resistance, and this assumption helps to explain why overtly political films are celebrated and programmed internationally, to the near exclusion of other genres. Thus an arty, nonactivist director like Wang Bing is regularly lionized as a heroic, even subversive, dissident. Indeed, programmers and the press have portrayed the events of 2014 as the violent crushing of subversive radicals, but $A$ Filmless Festival actually documents quite aboveboard negotiations with power, couched in a rhetoric of artistic freedom-as opposed to a straightforward act of political subversion and dissent. Unfortunately, this engagement became a losing strategy for the film festivals.

The final end of the festival era was marked by a comprehensive film law enacted in March 2017. While it cleared up confusion about regulations and sought to streamline production, the law chilled the indie world. Whereas in the past, all manner of production and exhibition was possible across the country, now all films publicly exhibited in China require a "Dragon Seal"- - the green precredits title that signifies successful passage through censorship. Penalties for bypassing the censors are harsh. Income may be clawed away. Fines of as much as $\$ 30,000$ or up to ten times the amount of "illegal income" may be levied. Equipment may be confiscated.7 For the first time, the law specifically mentions film festivals, whereas earlier film festivals had a largely transactional and negotiated relationship to authorities due to being largely unregulated. As long as a festival called itself something other than a "film festival" in Chinese, there were literally no laws that would apply to it. Today, penalties for public exhibition of noncensored films can include being barred from screening films for up to five years. With this, the ruins of the independent film festival scene were codified by law.

But if the independent film scene is assessed outside of the discourse of resistance, the biggest change was the weakening or loss of cultural asylums, for filmmakers are still actually making films. Artists now face four basic choices.

Their first option is to quit production entirely (or to make films but not actively show them), but few have made a complete retreat.

Some have chosen exile (though it must be said that this is a voluntary, "soft" exile, so the term is probably a misnomer). This list is long and features many of the stars of the previous era. Ying Liang, Wang Hongwei, and Huang Wenhai have all gone to Hong Kong; Zhao Liang, to Thailand; Zhu Rikun, Wang Wo, Cui Zi'en, Zhao Dayong, and Xu Ruotao, to the United States; Fan Popo and Ai Weiwei, to Germany; Huang Ji, to Japan; Yang Lina, to Taiwan; and Wang Bing, to France. 
With the exception of Ying Liang, all these artists maintain a transnational practice and freely travel between China and their new homes. And with few exceptions, their films continue to be about China. ${ }^{8}$

The third choice is to submit to censorship. Zhang Xianmin slyly calls this "being Dragon-Sealed." Some of the old directors are following this route; however, this choice is most typical of a newly formed "independent" sector with high production values that is highly capitalized, plays by the rules, and can actually put food on the table. These films are created for television, web distribution, and VOD. Recently, China's first university-based documentary film school was established in Shanghai to feed this system. (Interestingly enough, its classes on documentary history introduce students to the highlights of the independent documentary of the last quarter century.) However, the filmmakers coming out of this school make conventional documentaries that typically show at TV markets, not film festivals.

A final route is to continue as if the film law had never been promulgated. A small number of filmmakers poke at the letter of the law by testing and negotiating its actual limits. A good example is the veteran documentary director $\mathrm{Xu}$ Xin (Karamay, 2008). His latest film, Changjiang (A Yangtze Landscape, 2017), is a stunning audiovisual trip up the Yangtze. Black and white, seamlessly mixing documentary and performance, it notes the contrast between rich and poor along the banks of the river. Xu Xin did not bother with the Dragon Seal, showed the film at prestigious foreign festivals Yamagata and Cinéma du Réel, and is currently presenting it at private screenings around China. However, such domestic venues are discreet, and few and far between. Alternatively, works aimed at the gallery scene rarely pass through censorship. For example, contemporary art titan Xu Bing was refused a Dragon Seal for the experimental Qingting zhi yan (Dragonfly Eyes, 2017), yet it screened with no problems at his major solo show at the Ullens Center for Contemporary Art in Beijing's 798 Art District. ${ }^{9}$ The brilliant film is a self-consciously contrived love story built entirely from surveillance-camera footage. Ironically, $\mathrm{Xu}$ and his staff found a surveillance image of a Dragon Seal to open Dragonfly Eyes, thanks to an odd online group of cinephiles who were netcasting their own screening series of pirated films.

\section{New Beginnings}

Because there is still a wide variety of films being made, calling them "post-independent" cinema would be to stay trapped inside the discourse of resistance. Outsiders have to be similarly wary of imposing frameworks on the festival scene, because programmers have no choice but to become "Dragon Sealed" and submit all films for review. There are many festivals playing amid the ruins of BIFF, Yunfest, and CIFF. Three are particularly important and make me just a little hopeful about this new beginning: the Shanghai International Film Festival (SIFF), the Pingyao Crouching Tiger Hidden Dragon International Film Festival, and the West Lake International Documentary Film Festival.

Shanghai is one of two massive, official film festivals (along with Beijing, which by all reports is something of a Potemkin-village affair, yielding little). It is easy to be cynical about this event, considering that it is run by the city government in collaboration with Shanghai Media and Entertainment Group, one of the largest media companies in the world. At one point, Marco Müller-the former director of Europe's Rotterdam, Locarno, and Venice film festivalswas headhunted by SIFF. He turned them down when he learned his mission was to boost the festival to five hundred films over nine days. ${ }^{\text {Io }}$ Size matters at SIFF. It added film and television markets, and bought the A-list moniker from the International Federation of Film Producers Associations. In 20I7, the festival attained its goal of five hundred titles-a staggering number that makes its catalog brick-like but also seems to give the programmers a certain measure of freedom. Dig deep enough, and a lot of great films can be found hidden in the ostentatious overload.

The documentary section is most interesting. Programmer Emma Xu has, interestingly enough, made space for filmmakers deeply identified with the earlier indie scene. In 2017, Du Haibin served on the jury. In 2018, Wu Wenguang, often called the godfather of the independent documentary, was on the jury. This seemed a paradoxical choice for Shanghai, so I asked Wu what he thought upon receiving the invitation. He was surprised:

The domestic film festivals and judging work that I participated in before were only for "independent film festivals"-for example, Yunfest, Beijing, Songzhuang, and Nanjing. I had never served as a judge for an "official" film festival. I had not even gone to these (to show my own film, to see a film, or for any other activity). I felt these festivals "had nothing to do with me." But I respect this kind of invitation to serve as a judge. I understand that the workers at this film festival are attempting some "possible change." (From the arrangement of the "non-competitive category" documentary film program, you can see that they are making a strong effort. $)^{11}$

The key phrase here is "possible change," a straight translation of you keneng de bianhua. ${ }^{22}$ (Note that a freer translation would be "the changes they can manage within the system.") 


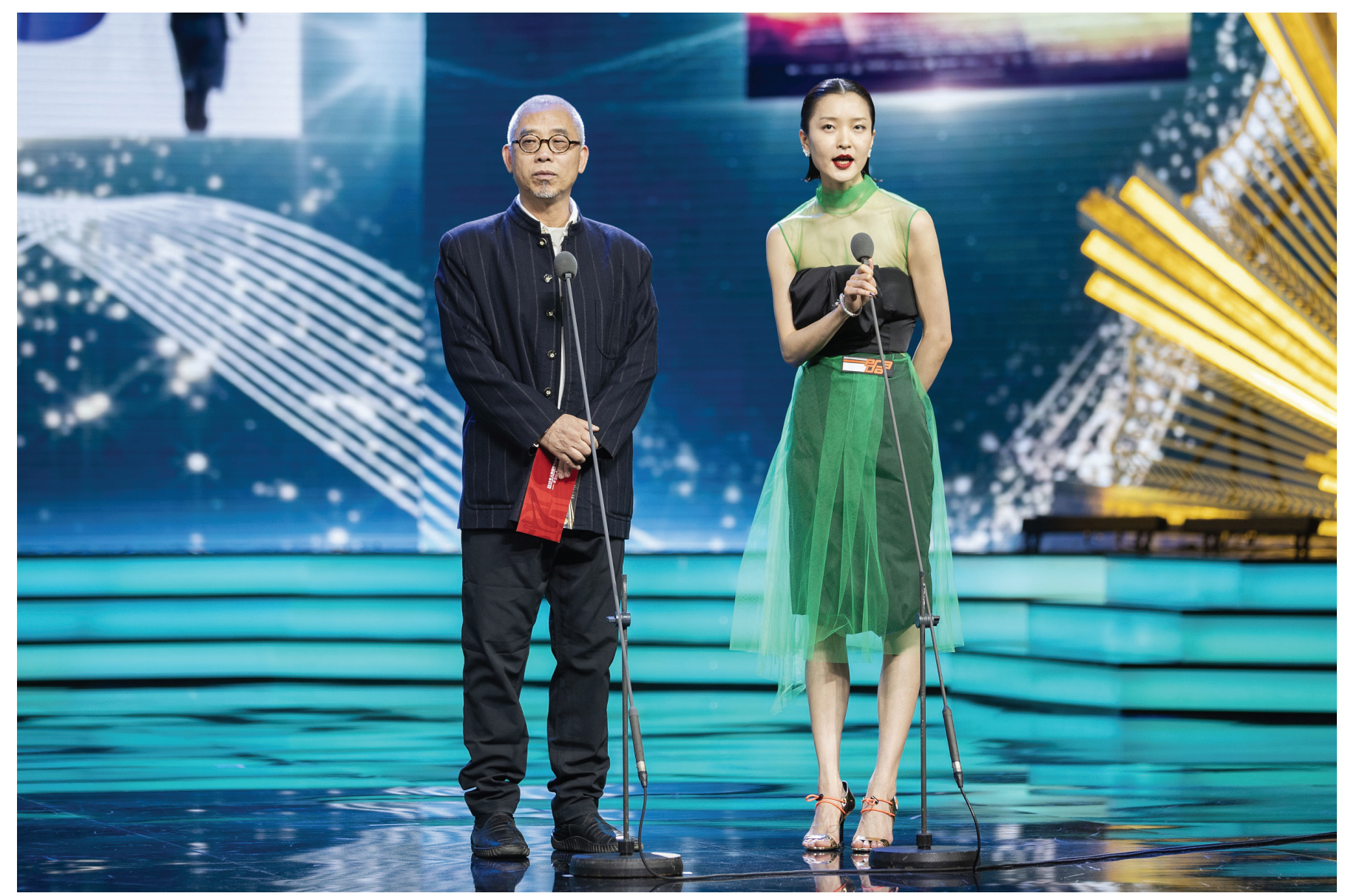

Wu Wenguang and super model Du Juan at the 2018 Shanghai International Film Festival awards ceremony.

Courtesy of Shanghai International Film Festival

Shanghai is a shiny, official affair, not a collection of rambunctious artists in a dusty artist village. The censorship review is still real, but expedited. These days, there is no shortage of slick made-for-TV and VOD documentaries modeled on the Discovery Channel on tap for such a festival.

However, $\mathrm{Xu}$ shoots high. Her international section includes the likes of Frederick Wiseman, Agnès Varda, and Hara Kazuo. To program their domestic equivalents means looking to the veterans of the independent scene. This is why she turned to Du Haibin and Wu Wenguang for jury duty. $\mathrm{Xu}$ is similarly opening up the screening slate, testing the waters by submitting work made entirely outside the system defined by the film law, and making a case for its importance. She is not always successful; for example, Zhao Liang's wonderful Bei xi mo shou (Behemoth, 2015) was rejected. However, she was able to show Wang Bing's Fang Xinying (Mrs. Fang, 2017).

The selection of Mrs. Fang attracted considerable attention. Wang Bing has rarely bothered to show his films in China. People there often joke that they must go to foreign festivals to see his work. Mrs. Fang is a good example of
Wang's ambition to winnow cinematic form down to simple structures by amplifying lived, material conditions to invite contemplation about larger philosophical questions. In this film, even history leeches away. The film is a close record of a woman's last weeks on her deathbed, mainly showing close-ups of Mrs. Fang surrounded by (often bickering) family members. Except for a couple of shots at the beginning, when she was already in a deep Alzheimer's fog, Mrs. Fang is catatonic throughout.

Toward the end - her end — Wang catches a tear running down her cheek. In an interview, he said: "She wasn't able to communicate, but there was a tear. That was enough for me to understand that there was still someone there and that she wanted me there." ${ }^{3}$ This is pure fantasy, of course, and probably a tell (to use the poker term): Wang must know that, not having received consent from Mrs. Fang herself, he is exploiting her miserable death for his own artistic ends and profits. Another tell: he excuses himself from her actual moment of death. If he were like other documentarians representing the very human traverse from life to death and had the informed consent of his subject, he would not have left at 
the very moment he had presumably been waiting weeks to film. Mrs. Fang is the latest of Wang Bing's ethical failings. He has sidestepped the consent issue from the beginning of his career, but nowhere is his for-art's-sake exploitation so egregious. Mrs. Fang is an exercise in cruelty.

I wish that SIFF had chosen a director other than Wang Bing and a better film to highlight. But, like Wu Wenguang, I am grateful for these efforts to complicate the documentary situation in China. Wu, in particular, admires SIFF's attempt to open up a space in territory he always felt had nothing to do with him. That is why he accepted the invitation, although he ignored its details about dress code and showed up looking like a poor artist. He ultimately conceded to a jacket for the red-carpet arrival and the ceremonies, but stubbornly refused the tie: there are still lines he would not cross! Similarly, he just finished a new film, but he has no intention of submitting it to the censors.

Redefining the line and opening up new spaces is the explicit agenda of the Pingyao Crouching Tiger Hidden Dragon International Film Festival (PYIFF). This is the pet project of director Jia Zhangke and Marco Müller, who bring a seriousness of purpose and vast experience to the event. The setting for the festival is truly spectacular. Pingyao is a U.N. World Heritage Site four hundred miles southwest of Beijing, near Jia's hometown of Fenyang. A walled city that was once a finance center for northern China, Pingyao is notable for its well-preserved and stunning architecture. Anyone who has seen Jia's films is familiar with its maze of brick lanes, arches, and massive ramparts. Many of its fine courtyard houses have been converted to boutique hotels. In fact, in his catalog introduction to the festival, Jia brands the event as a "boutique festival for the people." He wants to connect the festival to the small venues of early cinema-cafés and nickelodeons-but his phrasing captures its odd mix of local economic planning and transnational capitalism. Actually, this is precisely what makes it potentially important for the future of art-house cinema in China.

While Pingyao is hardly the rather crass marketplace that Shanghai presents, its catalogs make clear it is part and parcel of a local political program to connect its home province of Shanxi to national projects of soft power, local branding, tourism, and economic development at various levels of government.

The agenda is crystal clear at the festival venue-a spectacularly repurposed campus from an abandoned diesel engine factory, where the cavernous buildings now house exhibition halls, coffee shops, gift shops, restaurants, and festival offices. One empty husk of a building has been transformed into a grand space for press conferences. Another massive structure has a restaurant/bar area adjacent to a row of big black cubes, each containing a theater with excellent sound and projection. There is also one large, very fine movie theater, and a huge outdoor amphitheater with evening screenings — outdoor events reminiscent of Locarno, only really cold.

A red carpet stretches down the main street of the campus. Every dusk, Müller and Jia greet a selection of directors and actors there for the TV cameras. The crowds lining the carpet are sparse, making the scene slightly pitiful—clearly designed for televisual and online spectacle.

Actually, foreign observers have been collectively scratching their heads at Jia's recent moves. He has been busy diversifying into restaurants and other businesses, and has even entered politics. PYIFF looks unnervingly glossy. If it all seems disappointingly out of character to admirers of the Jia of Zhantai (Platform, 2003) and Shijie (The World, 2004), it shows how Pingyao has to take on the trappings of the glamorous A-festival scene in order to secure buy-in from local politicians and authorities. Some may scoff at this, but the fruits of these efforts are palpable in the fine quality of the facilities, the excellent projection conditions, and the careful selections by the high-powered programming team that Müller and Jia have assembled. It's all connected to a strategy underlying the festival. At the inaugural edition of the event in 2017 , Jia had said:

When I shot Platform, young filmmakers were struggling due to a lack of funding. Now, money is not the biggest issue, but rather the fact that nobody seems to care about arthouse cinema any more. I hate going to multiplexes, so I wanted to create an independent space for the audience and filmmakers to really immerse themselves in film. ${ }^{14}$

Müller has worked at the stratospheric levels of the global film system and has produced feature films. In designing this "boutique" festival, he is highly self-conscious about Pingyao's position within the local, national, and international circuits to which it belongs:

Well, the festival scene in China has to be acknowledged for what it is and also for what it should be. I think that the institutional festival only makes sense in countries where there is still a need to uphold the necessity of the immediate passage from the aesthetic power of attraction of a film, through a festival presentation, to the revelation of a certain market value that lay hidden in the film-something that can only be revealed through the successful screenings and the way the very special sectors of viewers, especially young viewers, participate. ${ }^{15}$ 


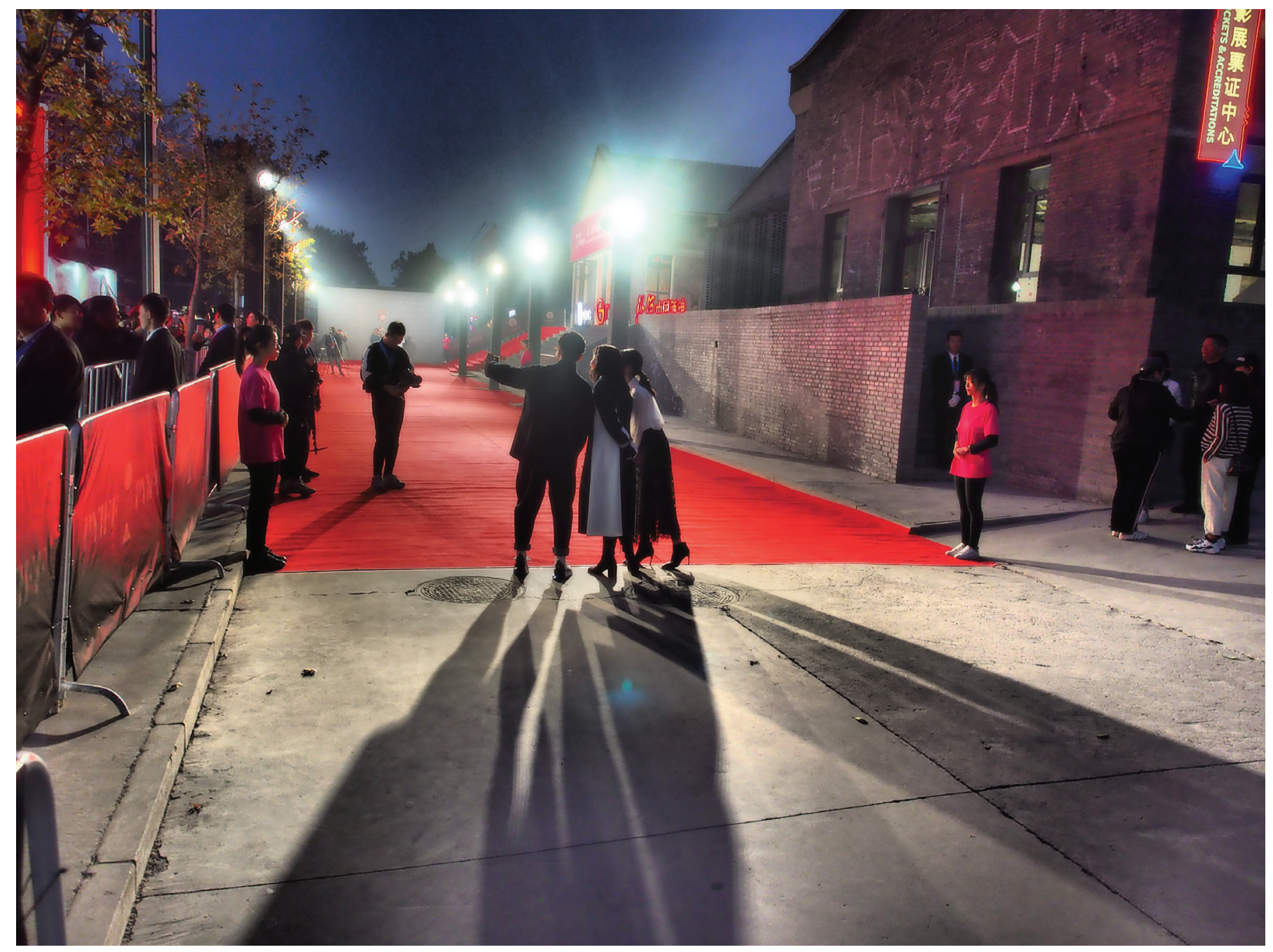

The spectacle of the red carpet at the Pingyao International Film Festival.

There is a disconnect between producers and audiences that Jia and company hope to ameliorate. On the ground at Pingyao, the logic behind Jia's perplexing moves makes sense. Pingyao inserts itself into an institutional space between SIFF/BIFF and the ruins of the previous indie festivals. Jia estimates that there are over fifty million potential audience members with an inclination to watch interesting, artful cinema. It is a huge number that could easily sustain what in most countries would be called the independent sector. But at the moment, there is a radical disconnect between these kinds of filmmakers and their potential audience. Jia and Müller are attempting not only to cultivate this new audience but also to address the puzzle of distribution in the wake of the failure of the Arthouse Alliance. ${ }^{16}$ Each year, a small collection of films are carefully chosen and presented, in an attempt to leverage them into a broken distribution system that favors the popular film. This is a burgeoning film system awash in capital but suffering from a vacuum that Jia is cannily and admirably trying to fill. I went to
Pingyao dubious but left quite impressed. I would go so far as to say that Pingyao is a festival that looks a lot like the early Sundance but aspires to be present-day Sundance.

With slots for only twenty foreign, twenty domestic, and ten retrospective films, Pingyao has decided to exclude documentary. Thankfully, this function has been taken up by the West Lake International Documentary Film Festival, which, like Pingyao, had its second edition in October 20I8. Many filmmakers and programmers, like me, attended both festivals. West Lake takes place on the shores of a lovely lake in Hangzhou, near Shanghai. This is also a spot with a long history, famous for its art, poetry, and delicious tea. The festival is sponsored by the provincial government and the China Academy of Art, one of the top art schools in the country. (The festival's posters, catalogs, trailer, and ceremonies sport incredible design, naturally.) It also serves as the main venue, with other screenings at local universities.

The art school has begun teaching film and video, too, and recently added Du Haibin to its faculty. The programming 
team is drawn from the faculty, who select a competition section of twenty works (eleven features, six episodic series, and three shorts). There is also an out-of-competition section of international documentaries. And there is something new to documentary film festivals in China: a pitching forum for twelve works in progress, with completion funds awarded to the winners. ${ }^{17}$

The West Lake festival presents itself as an intervention. The emphasis is most definitely on the art of nonfiction film—as signaled by its acronym, IDF, which confused many. The catalog explains that IDF is a slogan, not an abbreviation, and stands for "I Documentary Fact," which sounds a lot better in Chinese: wo jilu shishi. In an image culture where sanctioned documentary presents itself as the film of fact, this slogan is a loud declaration of nonfiction films based on subjective, artistic vision and free expression.

In this manner, West Lake clearly links itself to the previous independent documentary tradition, building a new structure amid the ruins. One could not help noticing the parallels, for it often felt like the old Yunfest, taking place in spare institutional spaces with spotty projection and poor sound. What's more, on the first day of the festival, the national government censorship office unexpectedly canceled nine films. All had passed censorship at the local level, which should have been enough. The reasons for the cancellations remained obscure, while everyone on the ground exchanged knowing glances or rolled their eyes: here we go again.

But this time was different. No protests were staged. The festival did not migrate to private spaces (although the jurors were able to watch all the films and granted an award to one of the excluded films). There were no speeches. No festival in a bag. At West Lake, they rolled with the punch and did what they could.

Although Zhao Liang's Behemoth was dropped by SIFF when it failed to pass censorship, his Guji de shengyin (A Solitary Human Voice, 2018) was one of the highlights of West Lake. This short film on Chernobyl is a dry run for a feature project about nuclear-accident sites; he is currently shooting at Three Mile Island and Fukushima. The film consists of a set of quiet tableaux shot inside Chernobyl's radioactive exclusion zone, slowly crosscutting between abandoned buildings and an old woman who refused to evacuate. Originally one of a small group of stubborn survivors, she is now the only one left alive. Sitting silently, lying in bed, she appears profoundly alone. Because she only sits, sighs, and sleeps, it feels as though her present existence is mainly spent dwelling in the past. Snippets of first-person narration are superimposed over beautifully composed images. A kind of inner monologue,

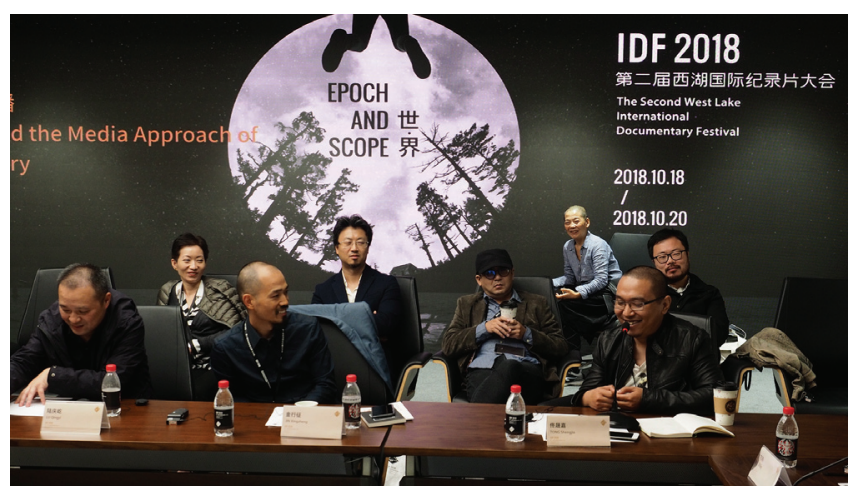

A forum at the 2018 West Lake International Documentary Festival.

they narrate her experience of the slow-motion disaster of radiation poisoning.

However, halfway through the film it becomes evident that the bits of text are the answers from many different survivors to unheard questions; in fact, Zhao drew them from Nobel laureate Svetlana Alexievich's massive book of oral histories, something revealed only in the end credits. ${ }^{18}$ The effect is uncanny, gradually transforming the woman's inner monologue into the voices of the dead. She takes on a mysterious iterative quality, her silent "voice" standing in for untold numbers of victims whose ghosts haunt the dirty, radioactive ruins. ${ }^{19}$

Zhao Liang is an accomplished still photographer, and his cinematography grows more stunning with every film. He shot $A$ Solitary Human Voice on an 8K Red, and was noticeably perturbed at the somewhat fuzzy video projection in West Lake's classroom (yet another similarity to Yunfest and other unofficial events).

Another whiff of festivals past came from the faces. Many of the pioneering directors were in attendance, and the festival made a delicate effort to carve out on- and offstage space for discussions. The most important was the festival's forum, a quasi-academic set of roundtables that ran all day, every day of the festival. On the face of it, this schedule had something to do with the venue of the art academy. However, it was clearly a way of providing a precious opportunity for visitors to meet and talk. The forum was organized by Zhang Xianmin, who, having been "encouraged" to avoid programming films, ensconced himself in the forum every day with forty-odd guests. Participants were a mix of filmmakers, programmers, distributors, critics, and academics. The list included a who's who of the documentary scene in China, including Du Haibin, Ji Dan, Zou Xueping, Yu Guangyi, Gu Tao, and many others. On the last day, Zhang switched to a "seminar" format - the only difference being that entrance to the room was by invitation only. In effect, they converted the room into a safe space where the local artists could comfortably share their recent experiences. 
This kind of venue for sharing and community building was one of the great losses of the last decade, and in recent years such opportunities have arisen mainly in small workshops in mostly rural areas. However, although West Lake had the vibe of Songzhuang and Yunfest, many agreed it still felt different. Akiyama, one of the forum and seminar participants, said:

In the days of the cultural asylum, the artistic field was a gray zone. There was no black and white, and filmmakers did not have to think about censorship. But now they have to decide whether to submit to review or not. Although they can no longer show their works freely, they can still come together at workshops or a precious venue like West Lake. I respect their efforts. Gatherings at places like this are homecomings. It shows that they have an imaginary home in their hearts. ${ }^{20}$

The Shanghai International Film Festival cannot easily provide such a space because of its official feel, its bewildering scale, and the immensity of the city in which it takes place. However, both Pingyao and West Lake try to provide filmmakers and their audiences a kind of home. Pingyao's public spaces were lively, filled with people chatting and networking; at the same time, its evening parties were often empty, sad affairs, suggesting that Jia's project remains very much a work in progress. In comparison, West Lake has already established a place for an annual homecoming, even if, for the time being, it probably cannot aspire to the status of asylum.

\section{Author's Note}

This essay would not have been possible without the gracious support of colleagues like Li Xianting, Zhang Xianmin, Wu Jueren, Emma Xu, David Rolston, Ben Brose, Zhang Yaxuan, Shelly Kraicer, Xiaobing Tang, Akiyama Tamako, Marco Müller, Ma Li, Nakayama Hiroki, Nakajima Seio, Wang Wo, Zhou Jiali, Wang Hongwei, Wang Shu, Cong Feng, Xu Xin, and Wu Wenguang.

\section{Notes}

I. I also wrote: “A truly independent documentary movement [in China] has taken that familiar waveform marked by explosive growth, newness everywhere, and exhilaration over innovative moviemaking and ways of viewing." See Abé Markus Nornes, "Bulldozers, Bibles, and Very Sharp Knives," Film Quarterly 63, no. I (Fall 2009): 50.

2. Kevin B. Lee, "Beijing Independent Film Festival Goes Dark after Record Turnout, Heads Underground," Indiewire, August 2012, www.indiewire.com/2012/o8/beijing-indie-filmfestival-goes-dark-after-record-turnout-heads-underground$45464 /$.
3. The film is available on Wang Wo's YouTube channel: https:/youtu.be/_WSctD7D 3 MQ.

4. Wang Hongwei, personal communication, October 30, 2018.

5. Xiaobing Tang, Visual Culture in Contemporary China (Cambridge: Cambridge University Press, 2015); Akiyama Tamako, "Karuchuraru asairamu: Chugoku indipendento dokyumentarii no tomei na toride" [Cultural asylum: The invisible fortress of Chinese independent documentary], Taishu Bunka I6 (March 20I7): 37-5I. Tang's polemic is less helpful because his main counterexample analyzes the mainstream, popular cinema; it surely deserves more attention, but he does not show a productive way forward to approach the indies.

6. Akiyama, "Cultural asylum," 46.

7. The text of the law is online at www.npc.gov.cn/npc/xinwen/ 2016-II/o7/content_200i625.htm.

8. Ying Liang recently finished a deeply felt, strongly autobiographical film, Ziyou xing (A Family Tour, 2018). The main character is an amalgam of friends who share the experience of exile. Observers in the know will notice costuming that includes T-shirts and bags from Yunfest, Songzhuang, and other festivals that no longer exist. It is a film that could only be made outside of the PRC, with characters from Taiwan, Hong Kong, and the mainland saying the things that everybody wants to say but can't.

9. Xu Bing, personal conversation, Ann Arbor, Michigan, October 9, 2018.

Io. Marco Müller, personal conversation, Pingyao, China, October I6, 2018 .

I I. Wu Wenguang, personal communication, October 3i, 20 I 8.

I2. Or, pushing forward the connotative meaning and spun in terms of Akiyama's asylum, it could be loosely rendered as "the changes possible within invisible boundaries."

I3. Daniel Kasman and Christopher Small, "Inner and Outer Space: Wang Bing Talks about Mrs. Fang," Cinema Scope 72 (Fall 20I7), http://cinema-scope.com/cinema-scope-magazine/ inner-and-outer-space-wang-bing-talks-about-mrs-fang/.

I4. Marta Balaga, "Marco Müller and Jia Zhangke: Organisers, Pingyao Film Festival,” Cineuropa, July I I, 20I 7, https://cineuropa.org/en/interview/342502/.

I5. Marco Müller, personal conversation, Pingyao, China, October I6, 2018.

I6. The Nationwide Alliance of Arthouse Cinemas was established in 2016 to much fanfare; however, it was forced to move under the umbrella of the National Film Archive, which is too underfunded for the Alliance to make a real difference.

I7. The first feature-film pitch session was at the 2007 Shanghai International Film Festival. Pingyao also has a pitching forum.

I8. See Svetlana Alexievich, The Unwomanly Face of War: An Oral History of Women in World War II (New York: Random House, 20I7).

I9. More specifically, it exhibits a pseudo-iterative quality; see Marsha Kinder, "The Subversive Potential of the Pseudo Iterative," Film Quarterly 43, no. 2 (Winter I989-90): 2-I6.

20. Akiyama Tamako, personal conversation with author, Hangzhou, China, October 20, 2018. 